\title{
Uma utopia do Cinquencento: "Mondo Savio e Pazzo", de Anton Francesco Doni ${ }^{1}$
}

Carlos Eduardo Ornelas Berriel

O Mundo Sábio e Louco, de Anton Francesco Doni, corresponde a uma das primeiras obras a compor o gênero utópico em sentido estrito. Foi publicada em 1552, 36 anos depois da Utopia de Thomas Morus (1516), e na literatura italiana é a primeira obra a realizar esse gênero. Permanecia até agora inédita em português.

Anton Francesco Doni nasceu em Florença a 16 de maio de 1513, portanto no início do pontificado do também florentino Leão X, filho de Lorenzo de Medici. Era filho de Bernardo d'Antonio, fabricante de tesouras, amolador de facas e comerciante. Muito jovem tornou-se servita no Convento da Annunziata, com o nome de Frei Valério, mas, pelo que os biógrafos puderam deduzir, era desprovido de vocação. $\mathrm{O}$ convento era-lhe um lugar conveniente para fugir das asperezas da vida, oferecendo conforto ao corpo e instrução. Mais tarde, em 1540, trocou o hábito de monge regular pelo de padre secular, por fuga ou expulsão não se sabe. Nessa condição peregrinou pela Itália setentrional, iniciando uma vida errante, rebelde, trabalhosa, repleta de lutas e desenganos. Em busca de protetores, esteve em Gênova, Pavia e Milão. Fixou-se em Piacenza para estudar Leis, mas como não tardou a descobrir que esse estudo também não lhe convinha, buscou serviço junto a senhores e prelados, tornando-se cortesão - certamente muito inferior às exigências construídas por Castiglione. Esteve em caráter precário e fugaz nas cortes de Roma, Veneza e Piacenza, até que, voltando a Florença, fundou uma tipografia, mas com pouca fortuna. Sofreu a hostilidade dos Giunti, e escassa proteção de Cosimo de Medici, o que levou ao encerramento das atividades da gráfica. Ganhou melhor a vida imprimindo em outras 
tipografias as suas próprias produções, que compunha rapidamente, e as traduções que fazia de outros autores. Retorna às peregrinações, por Roma e Veneza, fixando-se finalmente no Vêneto, em 1547. Este foi o começo do período mais fecundo de sua vida de escritor e editor. A partir de 1555 vivia solitário num torreão abandonado, de onde saía à noite, nu como um louco e tocando um alaúde. Após um intervalo de três anos em Ancona, onde também fundara uma tipografia, retornou a Monselice, para morrer em setembro de 1574.

Doni foi um espírito inquieto, curioso, audaz e litigioso, e nos chegaram dele testemunhos de sua polêmica com L. Domenichi e com Pietro Aretino. Sobretudo foi um espírito bizarro, de acordo com o que aparece em seus escritos, que foram de todo gênero, em verso e prosa. No geral todas as suas obras possuem um caráter de miscelânea, na qual reina a confusão, num estilo caudaloso e intrincado. São textos ricos de novos e vivazes fermentos, atuantes em várias direções, inclusive a social. Começou com algumas Lettere (1543) e com os Dialoghi della Musica (1544) e do Disegno (1549), e continuou com a Prima e Seconda Libreria (1550-51), constituídas de uma grande quantidade de bisbilhotice, boatos, zombarias, recolhidas sob o título geral de A Abóbora (La zucca,15511552), com discursos sobre Os Mundos (I Mondi, 1552-53), com Os Mármores (I Marmi, 1553).

Os escritos de Doni (lidos, como ele mesmo disse, antes de serem compostos, impressos antes de acabados) são de uma facilidade endiabrada, e chegando ao pedantismo, tratam - sem preparação sólida, mas com perfeita adequação às necessidades espirituais da scapigliatura quinhentista - de toda sorte de assuntos: da Moral Filosofia (1552), onde foram introduzidas muitas fábulas orientais, da Memoria e da Eloquenæa (Il Cancellieri, 1562), da reforma da humanidade (I Mondi), e assumem todas as formas: da comédia (Lo stufaiolo), da novela (esparsas em toda a sua obra), de patranhas (La mula, La chiave), do poema (La guerra di Cipro), da invectiva (La vita dell'infame Aretino). Segundo Trousson, Doni não rejeitava nem mesmo a pornografia. Sua obra adianta realmente, mais do que 
o próprio Aretino, o jornalismo moderno, pela prontidão com que percebe as correntes de idéias, julga os valores dos fatos, lhes anuncia as conseqüências; pela facilidade com que estabelece um tema e despeja escritos, que devem viver a vida da hora que passa e não mais. Existem escritos nos quais Doni parece anteceder Galileu na aceitação das idéias copernicanas, e outros nos quais parece prenunciar o socialismo, acolhendo os sonhos de Thomas Morus (publicou inclusive a Utopia deste último, traduzida por Lando).

A sua obra prima são I Marmi, nos quais, fingindo referir-se a discursos ouvidos em Florença, de pessoas sentadas a bater papo nos "mármores" de Santa Reparata, Doni representa aquilo que foi a vida intelectual do seu tempo. A língua é do mais vivo e eficaz parlare florentino, apesar dos motes parecerem hoje menos agudos do que deviam parecer aos contemporâneos.

Sua utopia, Il Mondo de' Pazzi, constituída pelo sexto diálogo dos Mondi (1552), está muito distante do ideal da aristocrática Thélème. Recordando-se da Sforzinda de Filarete, Doni imagina uma cidade com a planta com formato de estrela, tendo ao centro uma igreja mais alta que a catedral de Florença; este templo possui cem portas das quais partem cem ruas em direção às cem saídas da cidade. Reencontramos aqui aquela paixão pelo urbanismo, a simetria e o equilíbrio geométrico, reflexo de uma harmoniosa organização humana. Há ecos de Platão, Morus, Alberti, Leonardo, Guevara...

Doni se revela além do mais um pensador rígido e violentamente crítico. A terra produz apenas uma única espécie de fruta ou de verdura, e os camponeses se especializam em um só tipo de cultura. As ruas são ocupadas por aqueles que praticam ofícios complementares: se de um lado estão os doutores, do outro estarão os boticários; aqui os sapateiros, e em frente os comerciantes de peles; e assim por diante. Mas Doni exige sobretudo uma igualdade rigorosa, um comunismo integral - o mais próximo possível à lei da natureza - que exclua a própria família. Duas ruas constituem o bairro das mulheres, comuns a todos: "Deste modo 
não existiam parentelas e se ignorava de quem alguém era filho”. Todos possuem moradias iguais, a mesma comida: "quem não trabalha não come". Os hospitais acolhem os doentes, os velhos e os enfermos, mas se pratica uma severa eugenia (as crianças deformadas são jogadas num poço). Portanto todos os homens do novo mundo são "belos, bons, sãos e frescos". Essa utopia não tem uma forma precisa de governo e não possui leis, nem polícia, nem tribunais, nem exército. As crianças criadas em comum aprendem um ofício e não se preocupam muito com os estudos. A religião é sem ritos, ainda que o povo, a cada sete dias, reze no templo "com grande devoção"; Doni parece próximo de negar a imortalidade: um morto é apenas um corpo - um pedaço de carniça - jogado na terra sem muita cerimônia.

Desde Thomas Morus, autor da palavra, é chamada "Utopia" toda descrição de uma sociedade que se supõe perfeita em todos os sentidos. Classifica-se como "utópico" a todo ideal de sociedade humana que se supõe maximamente desejável, mas comumente considerada inalcançável. A explicação mais geral da gênese desse gênero literário, tão próximo da História, da Filosofia e da Política, segue basicamente a idéia de que a Utopia seria gerada pelo processo burguês de racionalização da vida. Essa explicação não basta por si, de forma alguma: as circunstâncias da Reforma e da Contra Reforma são obrigatórias.

No Renascimento talvez possa tenham surgido os primeiros grandes experimentos, depois da Antigüidade, de racionalização da vida, individual e associada. Para os homens daquele tempo, possuídos pela idéia de guiar por si mesmos a sua sorte e o destino da humanidade, foi elemento de satisfação poder fixar normas de conduta e regulamentar cada aspecto da vida prática. Todos podiam e deviam responder a critérios universalmente válidos; para cada setor de atividades havia uma norma, um guia, uma regra, um código; surgiram assim os tratados sobre o perfeito cortesão (como o de Castiglione), sobre o perfeito ministro, sobre o perfeito homem do mundo. Inclusive modelos de urbanística, como o de Leonardo da Vinci, o qual, ilustrando no seu Códice um de- 
senho de cidade perfeita, detalhava como deveriam ser nesta as ruas, casas, esgotos etc. Pelas ruas altas não deveriam andar carros nem outras coisas similares, mas apenas gentilhomens; pelas baixas deveriam andar carros e outras coisas somente para uso e comodidade do povo. De uma casa extraordinária a outra, deixando a rua baixa no meio, por onde chegam vinho, lenha etc. Pelas ruas subterrâneas estariam as estrebarias e outras coisas fétidas. De um arco a outro devem existir 300 braças, por onde entraria luz, e cada arco deveria ter uma escada em caracol. "Tanto seja larga a rua quanto é a universal altura das casas." Façam-se fontes em cada uma das praças. E assim por diante.

A cidade descrita por Leonardo é já, de certa forma, utopia; é uma exigência completamente racional, que espera ser traduzida em prática. De modo simples, podemos dizer que o homem do Renascimento experimentava a idéia de se conceber como autor de sua própria existência.

As utopias, cujo número supõe-se alcancem a cifra de 2.500 , são muito distintas entre si, mas possuem em comum o fato de descreverem não apenas uma sociedade ideal e perfeita, como também a descrevem de modo detalhado. É provável que nenhum dos seus principais autores creia que a sociedade descrita seja realizável. Mas foram movidos pelo desejo de criticar a sociedade de sua época e de propor reformas, que são cumpridas na sociedade utópica.

As utopias foram criticadas muitas vezes como promotoras de uma atitude cega para as "realidades humanas", tais como as ambições, o desejo de poder etc. Segundo os opositores, é fácil pensar numa sociedade ideal quando não são levadas em consideração as realidades, as quais sempre oferecem obstáculos. Uma sociedade utópica, já foi dito, funciona perfeitamente apenas porque funciona no vazio. Também já foi dito que o espírito revolucionário utópico se aniquila por si mesmo, já que numa sociedade perfeita não cabem revoluções nem, portanto, mudanças e progresso. 
Depois de Thomas Morus, a utopia se difunde rapidamente rompendo um silêncio que durara vários séculos, e multiplica-se em escolhas totalmente contraditórias. É como se o experimento de Morus tivesse repentinamente liberado um imenso desejo de criticar e de construir, de sonhar ou de ironizar. Basta seguir a ordem cronológica das sucessivas manifestações para constatar até que ponto é a utopia o gênero adequado para concretizar as aspirações mais diversas, indo da utopia social e política à utopia teológica ou alegórica. Ao lado da miragem de grandes descobertas que amplia os horizontes, se afirma a miragem da cidade justa, equilibrada; os acontecimentos religiosos, econômicos e políticos do século, a aspiração humanista à tolerância e à liberdade encontram na utopia seu meio de expressão ideal. Católica ou protestante, teocrática ou "científica", comunista ou aristocrática, a utopia apresenta todos os aspectos de uma reflexão sobre o homem. Se Morus havia instalado na sua ilha um deísmo racional inspirado pela evidência da natureza, outros mostram-se menos tolerantes, sendo Francesco Patrizi da Cherso, com a sua aristocrática e clerical "Città Felice", o exemplo meridiano.

Todavia muitas modificações se verificaram na Itália no desdobramento do Concílio de Trento, no qual a Igreja Católica, decidida a definir-se diante do protestantismo, esclarece e enrijece as suas posições dogmáticas. Esse fato leva a um ofuscamento do pensamento utópico, e não apenas na Itália: o gênero utópico reflete em geral as tensões da épo$\mathrm{ca}$, a difícil busca do equilíbrio entre tradição e reforma. Na segunda metade do século a obsessão da religião e do rigorismo ético influi pesadamente sobre o sonho da cidade ideal, que assume uma rigidez e uma austeridade nas quais o humanismo não pode mais ser reconhecido.

Doni, entretanto, não se preocupou muito com problemas religiosos: a sua cidade ideal, essencialmente plebéia, é antes de tudo uma cidade terrena na qual as preocupações políticas e econômicas superam as aspirações espirituais. $\mathrm{O}$ transcendente não é esquecido mas relegado a segundo plano, e é apenas a razão que organiza e legisla. Trata-se de um radical nivelamento social. 
Anton Francesco Doni é um caso excepcional no Cinqüecento: não crê nem em valores humanísticos que preparem o homem para o saber e para um papel ativo na sociedade, nem na religião que não se ocupa dos males terrenos. Elementar, violento e igualitário, o comunismo de Doni é sobretudo uma reação violenta contra as estruturas sociais existentes: isso é de inspiração plebéia, não humanista. Diferentemente de Morus, Doni não se propõe jamais a elevar o espírito do homem, a torná-lo consciente da nobreza de seus deveres. Eliminando a nobreza, o clero parasita e as diferenças sociais, parece limitar-se a assegurar à maioria uma possibilidade material de vida. A sua iniciativa é portanto essencialmente destrutiva: na sua cidade não existe nem mesmo um governo modelo, porque Doni, que tem pouca confiança na natureza humana, não acredita em qualquer instrumento de governo. Ao sonho humanista da cidade ideal prefere a segurança de uma existência elementar, conforme à lei da natureza. Doni é um escritor que, diferentemente de outros autores de utopias do Cinqüecento, não escreve para príncipes e sábios, mas para o povo, desejoso de soluções simples e diretas.

\section{Bibliografia}

S.Bongi, Vita e catalogo delle opere di A.F.Doni, na edição de Marmi, a cura de P. Fanfani, Florença, 1863; E. Chiorboli, A.F.Doni, in Nuova antologia, $1^{\circ}$ maggio 1928; A.F. Doni, I Marmi, a cura de E. Chiorboli, Bari, 1928, 2 vols. 


\section{O mundo sábio e louco}

\section{Do Sábio Acadêmico peregtino aos leitores:}

Depois de ter virado e revirado meu cérebro para decidir sobre o que deveria vos dizer nesta epístola, finalmente cheguei a uma conclusão. Tereis, talvez, prazer em saber aquilo que eu havia caraminholado para vos dizer. Esta seria uma pergunta que certamente faria aquele que diz: quem vai atrás dos problemas dos outros não pode ser sábio. Estou muito contente de vos dizer alguma coisa sobre isso. Antes admirai com o nome, se eu deveria chamar-me Sábio ou Louco; se eu me batizasse de maluco, tudo aquilo que eu houvesse escrito as Senhorias Vossas tomariam por maluquice. O dizer-se sábio não quer dizer nada, pois a isto se responde dizendo que mesmo os doidos varridos não se têm na conta de loucos, mas de sábios. Se portanto vós me chamardes pelo meu nome não seria grande coisa, porque Sábio quer dizer em língua italiana, literalmente, Louco público e notório.

A segunda coisa que eu astrologuei no meu cérebro foi o título deste novo Mundo, e após ter caraminholado por seis ou sete horas, cravei firme no nome de Mundo de Sábios, ao qual se lhe põe a brida sobre o pescoço para que possa correr à rédea solta entre os Sábios e os Loucos; e podeis chamar a ele [Mundo] e a mim Louco e Sábio e Sábio e Louco, se quiserdes. Se acontecer de vós o chamares Mundo hermafrodita não darei a menor importância, porque a novela que eu pensei ultimamente em vos contar está prontinha para começar, e é esta que se segue.

Dizem que houve uma Era dos Adivinhos, quando as pessoas sabiam o que ia acontecer dia após dia e de hora em hora, e estas adivinhações vinham através do astrolábio e por meio de Capricórnio e Câncer (pois que continuem a vir!), e sabia-se que todos aqueles do país, no qual estes borboletões habitavam, haviam de tornar-se loucos, louquíssimos; e que esta loucura haveria de durar para eles várias semanas, e sabe Deus de que jeito se curariam. E este acontecimento deveria se dar porque 
havia uma grande seca, e aguardava-se uma grandíssima água; daí o grande fedor que o terreno deveria fazer: batendo ele no nariz, era de amolecer os miolos. Assim estes astrólogos, ou adivinhos, como prefiro dizer, antevendo esta loucura, se juntaram, isto é, uniram todas as suas sabedorias numa só, e ordenaram que se construísse um salão com três ou quatro camadas de paredes; e o fizeram revestir com pedras, e taparam todos os buracos e todas as frestas das saídas e das janelas, de modo a que o fedor da terra não chegasse até seus cérebros.

Eis que chega o fedor, pois começou a chover, e eles num instante correram a entocar-se lá dentro, naquela casa maluca que haviam mandado fazer num belo lugar. Neste caso as senhorias deles estavam mais para loucos furiosos; seja lá como for, disse Cato, haviam imaginado fazerem-se senhores dos outros, dizendo: "nós não sentiremos o fedor e não enlouqueceremos; já os outros, sentindo o mau cheiro, enlouquecerão; nós seremos os sábios, e eles os doidos; já que assim determinam as ordens (ler 2.F.F. de consultis; codice $4 \mathrm{~m}$. de finibus, e texto p.s.f.f.c. de nonnulis) que os sábios governem os loucos; ergo, nós seremos senhores de todo este território"; a essa altura entre eles havia uma confusão de trapos, um saltar de alegria, um esfregar de mãos uma na outra e o cu na terra, rindo-se escancaradamente. Resumindo: eles pareciam estar no cio como os gatos de janeiro, lá dentro, quando escutaram vir abaixo aquele aguaceiro, pois chovia a cântaros; e as cadeias viriam a calhar para eles. Passadas enfim a enchente e a chuva, os rios chegaram para todo mundo na cabeça, e daí começaram a fazer mil maluquices. E pularam fora, para apoderar-se da terra e assenhorear-se da coisa toda. Acrescentarei ainda que estes sabichões fizeram certos vasos, os quais em dado momento se fechavam através de um engenho, e os puseram em alguns lugares secretos onde, no tempo da chuva, quando o fedor estava no ar, e os vasos se encheram daquela fumaça, e foram tampados. Aqueles vasos existem até hoje, e sempre aparecerá alguém para os multiplicar, e quando, por desgraça, num belo dia, eles caírem nas nossas mãos, e nós os cheirarmos, num instante daremos pinotes e ficaremos com o miolo mole. Creio que 
um destes potes fosse aquele de madona Pandora; que tinha dentro todos os males e que saíam fora (se o texto não falha) às goladas: porque ser louco varrido ou ter o cérebro derretido é carregar todos os males nas costas, quer estejam ou não estejam no mundo. E não acreditem naquelas zombarias que fazem os poetas a respeito dos peidos, que daqueles saíram todos os defeitos e as doenças uma a uma, e que o sono nos ficasse dentro. Mas sim! Ser doido, eu lhes digo, é a melhor coisa que há. Ainda que aquele pobre Orlando devesse inalar o vaso de Angélica (isto é, o que Angélica possuía), que deveria ser também aquele um destes: e enlouqueceu e precisou depois, para voltar a si, cheirar uma ampola.

Basta pois, o caso foi que os astrólogos adivinhos saíram fora, depois de alguns dias, sábios sábios sapientíssimos, que pareciam a reputação retratada a pincel, e caminharam em procissão diretamente para as pessoas, como se fossem cordeiros pascais. E quando viram o povo todo a correr, enfurecer-se aqui e ali, saltar rir gritar assobiar cantar dançar tocar, e quem fazia uma coisa e quem endoidecia uma outra; a coisa era assim, um rumor um estrondo um ribombar como se vós vísseis hoje num canto saltimbancos praticando modernos saltos, músicos de um outro num coro como os estorninhos que fizessem: am em im, am em im, o a e o a e o, com a voz, e outros músicos que tivessem a boca cheia de vento, inchadas as bochechas, com aqueles rostos feios, durante todo o dia fazendo: chiurlurú, liron liran, chiurlurú, liró liran; havia quem ficava pondo a língua para dentro e para fora, um outro ameaçava com o dedo tapando buracos e quem entregasse um documento em pergaminho fazendo: tutú, pitipú, tupitú, tu, até à noite; depois vistes oito ou dez danças de geração diversa, que saltavam e pisavam o terreno o dia todo, como se faz com a uva na tina: uma coisa parecida faziam estes loucos, que tinham a cabeça cheia daquela fumaça.

Os sábios, portanto, quiseram começar a impor regra a esta situação, e a dar ordens aqui e ali. Ah, ah, ah! dá-me vontade de rir. Pois a coisa aconteceu de outra maneira, porque os malucos eram muito mais 
mais mais numerosos que os sábios, e vendo que aqueles não faziam como eles, os doidos ficaram à sua volta com más palavras e piores atos, e afinal os sábios foram forçados a fazer como eles e enlouquecer contra sua própria vontade. Assim os sábios entraram para o número dos doidos, a despeito de si mesmos.

Eu, pois, cogitando criar um mundo de sábios e ter nome de sábio, duvido que não me torne louco e que não crie o mundo dos loucos; mas eu vos juro, pela minha fé, que, se vós sábios leitores não entrastes ainda no mundo dos loucos, contra a vossa vontade vos faremos entrar.

O Louco e o Sábio Acadêmico, por uma visão mostrada por Júpiter e por Momo em forma de peregrinos, vêem um novo mundo o qual por um é chamado Louco e pelo outro Sábio.

SÁBIO. Bem que me parecia sonho, bem que eu dizia que isso não podia ser, mas no entanto havia tanto de próprio, de vivo, e de bom, que me entretinha com grandíssimo prazer.

LOUCO. Às vezes os sonhos tornam-se realidades, e se tu quiseres me dar um imenso prazer, como já me deste tantos antes, isto é, que tu não viste nunca a mais bela coisa, começa do começo e desenha o lugar, e de cada coisa conta-me tudo nos mínimos detalhes. Parece-me grande novidade, realmente, que se encontre um outro mundo em que cada um goze tudo aquilo que se goza neste nosso, e que não tenham os homens senão um só pensamento, e que todas as paixões humanas tenham sido descartadas; começa, pois, desde o princípio do sonho.

SÁBIO. Parecia-me estar na nossa Academia e que entravam dois Peregrinos, os mais belos homens que jamais vira, e depois que thes fizeram ver e compreender as nossas ordens, depois de ouvidos os nossos raciocínios, escutadas as nossas lições e enredando-nos com isso, pareceu-me que um deles me pegava pela mão e o outro pela outra, e que me levavam a um Mundo novo, diferente deste.

LOUCO. Sei que eu não fui, nem me lembro de haver sonhado coisa alguma. 
SÁBIO. Estes peregrinos nos conduziram a uma grande cidade, a qual era construída em círculo perfeitíssimo à guisa de uma estrela. É preciso que tu imagines a terra desta forma, como eu a desenho no chão. Eis que eu te assinalo um círculo: faz de conta que este cercado sejam as muralhas e que no meio, onde eu faço este ponto, seja um templo alto, grande como a cúpula de Florença quatro ou seis vezes.

LOUCO. Será preciso que nós troquemos teu nome pelo meu, porque dizes coisas de doido.

SÁBIO. Escuta simplesmente. Este templo possuía cem portas, das quais tiraram a linha, como fazem os raios de uma estrela, e iam diretamente aos muros da cidade, os quais possuíam igualmente cem portas. Assim vinham a ser também as avenidas. Daí que quem estava no meio do templo e se virava num rodopio completo, conseguia ver de uma só vez toda a cidade.

LouCO. Agrada-me que chegando alguém nesta terra, estava fora de questão a possibilidade de errar o caminho, e aqueles de dentro ensiná-lo, que não é pouca quebra de cabeça ter que perguntar para onde se vai: daqui, dali, quebra a mão esquerda, retorna, pára, e não se vai mais adiante. Existiam outras cidades no mundo novo, como esta?

SÁBIO. Cada província possuía uma, assim como se fossem a Lombardia, a Toscana, a Romagna, Friúli, a Marca e daí em diante.

Louco. E o restante do país entre estas províncias, para que servia?

SÁBIO. Servia, que cada terreno frutificava segundo sua própria natureza; porque onde dava bem a videira, não se plantava outra coisa; onde o frumento, onde o feno, e onde a lenha, não se ficava dividindo o trabalho em várias coisas, se não uma destas coisas.

LOUCO. Agora sei por que nossas propriedades não nos rendem mais, como nós queremos: fazer frutificar num tipo de terra todas as coisas, aveia, vinho, azeite, frutas, grãos, lenha e feno. Onde em vez de um há dois campos de terra, que querem que dê tudo; e o terreno não é 
bom para tantas coisas: a sua natureza não o comporta; mas uma produz bem e dez mal.

SÁBIO. Assim me parece também. E todos aqueles que habitavam a aldeia que produzia vinho, não cuidavam de outra coisa senão de vinhas: plantar vinhas, cultivá-las, aumentá-las e governá-las; de tal forma que em poucos anos conheciam a natureza das plantas, e a experiência do passado produzia milagres com aquela planta.

LOUCO. Esta coisa me parece fantasia, tornar-se perfeito numa coisa.

SÁBIO. A cidade possuía em cada avenida duas artes; por exemplo, de um lado ficavam todos os alfaiates, de outro todas as lojas de pano. Uma outra avenida: num canto especial, numa esquina estavam todos os médicos. Uma outra rua: sapateiros que faziam sandálias e botas, de outro lado todos os curtidores. Numa outra rua: padeiros que faziam pão, e em frente moinhos que moíam a seco. Uma outra rua: várias mulheres que fiavam e teciam fazendo seus fios com perfeição, e aqueles no cruzamento teciam. Daí que chegavam a ser duzentas as artes, e cada qual não fazia outra coisa senão aquela.

\section{LOUCO. E com relação à comida?}

SÁBIO. Existiam duas ou três avenidas de estalagens, e aquilo que cozinhava uma cozinhava a outra, e tanto davam de comer a um quanto a outro. Estas não tinham outra atividade senão dar de comer às pessoas; e quando tinham necessidade de roupas, iam até o alfaiate e as requisitavam; assim com todas as coisas para o seu próprio uso; e eram repartidas as bocas; portanto tocava, por refeitório, digamos, cinqüenta ou cem ou duzentos homens; e como haviam dado de comer a tantos quanto lhes tocavam, fechavam a porta, de tal forma que todos percorriam gradualmente de uma em uma até a última. E de cada avenida cuidava um sacerdote do templo, e o mais velho dentre os sacerdotes era o cabeça da terra, o qual não possuía nada além do que qualquer outro. As vestimentas eram todas iguais, salvo que as cores, até os dez anos eram branco, até aos vinte verde, dos vinte aos trinta violáceo, até os quarenta verme- 
lho, e depois pelo restante da vida era negro; e outras cores não eram necessárias.

LOUCO. Também isto não me desagrada por tal eqüidade, pois se o nascer e o morrer correm por uma linha, é melhor que o viver também não saia da linha. Mas e quem adoecesse?

SÁBIO. Ia para a avenida dos Hospitais, onde era cuidado e visitado pelos médicos; e pelo menos a longa experiência e tantos médicos, que não tinham outras obrigações e colocavam todo o seu saber na cura, faziam bem todas as coisas.

LOUCO. Ih, que confusão se um rico fosse para o hospital.

SÁBIO. É uma coisa da cabeça; naquele lugar não havia mais do que um ou outro rico. Tanto comia e vestia um, e tinha a casa abastecida, quanto outro.

LOUCO. E para nascer, como eram as coisas?

SÁBIO. Uma rua ou duas de mulheres, e as coisas andavam do modo costumeiro. Não se sabia nunca quem era filho de quem, e deste modo a coisa ficava igual: porque nascendo, era criado, e quando chegava a idade certa, era posto para estudar ou aprender uma arte, segundo aquilo que lhe ditava a natureza.

LOUCO. Bendito seja este país! Que expulsa a dor da morte da mulher, dos parentes, dos pais, das mães e dos filhos, onde não se precisa jamais chorar.

SÁBIO. Jamais; porque se tirava da mãe o filho logo assim que estava grandinho e se entregava ao governo dos homens; e as meninas às outras mulheres, que se dedicavam a ensinar.

LOUCO. Aí neste lugar não havia roubos; porque não se saberia o que fazer com as coisas quem as houvesse tirado, porque, tendo como viver e vestir e ser governado, não havia embaraço. As mulheres deveriam ter os paninhos para se trocar e haver os empórios de cada coisa: "Toma esta velha, dá-me uma nova, eis a feia, dá-me a branca".

SÁBIO. Era assim mesmo. 
LOUCO. Mas aquilo das mulheres serem de posse comum, isso não me agrada.

SÁBIO. Ao contrário, por ser uma coisa de doido te agradaria.

LOUCO. E os dotes e as disputas?

SÁBIO. Mas que dotes e que disputas? Por qual motivo haveriam eles de disputar? Tudo era de posse comum, e os camponeses se vestiam como os moradores da cidade; porque cada um entregava o fruto de seu trabalho, e pegava apenas aquilo de que necessitava. Imagine se tivesse que vender, revender, comprar e recomprar!

Louco. Oh, que possam eles estar sempre de acordo com esta forma de viver! Pois que a turba dos notários, dos procuradores, dos advogados, e outras arapucas existem aos montes, e que tantos e tantos enganos e falsidades mercantis são difundidos nestes países. Pelo que vejo aí se deu mal a légua, o braço, o alqueire, a mina, a vara e tantas medidas existem no mundo para atormentar as pessoas.

SÁBIO. Cada sete dias faziam a sua festa, como nós o Domingo; e naquele dia não faziam outra coisa senão ficar no templo com grande devoção. E cada noite, duas horas antes de anoitecer, cada um fazia a festa comemorativa do seu trabalho. Assim em cada dia acontecia haver de cada coisa um pouco; e de manhã todos visitavam o templo e depois cuidavam de suas obrigações.

LOUCO. E os muito velhos, velhíssimos, que não podiam fazer nada, nem mesmo caminhar?

SÁBIO. Ficavam nos hospitais, e eram cuidados e mantidos todos da mesma maneira. E havia isto: cada um fazia ao outro o que gostaria que fosse feito a ele.

LouCO. Esta ordenação é boa para sair de sua boca, porque é coisa sábia. Mas e os monstros que nasciam, como por exemplo: corcundas, mancos, caolhos, etc. etc., e aí?

SÁBIO. Havia um poço grande, no qual se jogavam dentro todos, logo que nasciam, e portanto não se viam estas deformidades naquele mundo. 
Louco. A coisa me vai; mas não a louvo. $\mathrm{E}$ as enfermidades incuráveis, como são os cânceres, o mal francês, fístulas, pústulas, tísicas e outros males?

SÁBIO. Certa bebida espirituosa de risagallo ${ }^{2}$, e sublimados, e arsênico, e semelhantes xaropes os curavam em uma hora.

LOUCO. Quanta desonestidade!

SÁBIO. Oh, eles se entregavam ao que é belo, bom, são e fresco; ao que faz o bem e não o mal. Mas esses podem por legítima razão servir-se. Era realmente uma bela coisa sair do sufoco sem dificuldade.

LOUCO. Eu começo a compreender que desapareciam todos os vícios. Lá não tem brincadeira, porque ter dinheiro e não saber o que fazer, é um sonho.

SÁBIO. Dinheiro não nasce em árvore, disse o Cego. Aqueles que providenciavam a comida iam buscar a carne no açougueiro, o vinho na adega, a lenha no depósito. E sobretudo aquilo de tratar com igualdade as pessoas, me agrada, acabar com a inferioridade, com os ambientes escolhidos e outras cerimônias nossas.

LouCo. É verdade, é verdade. Concordo totalmente. Como eles faziam, com relação às mulheres para não haver confusão?

SÁBIO. Ter uma, duas, três, cem ou mil mulheres ao comando da S.V. não nos fará nunca cair em bizarria, porque se perde o amor, tanto mais que o homem se acostumou àquela lei, àquela mesmice sem amor.

Louco. Assim se deve fazer: deixar a coisa no benefício da natureza. Mas e se alguém se apaixonasse?

SÁBIO. Não sabes tu que o amor consiste na privação da coisa amada, naquela raridade, naquela dificuldade? Melhor deixar passar semelhantes apetites; e aquele hábito de não haver sofrimento, desmancha logo semelhante partilha.

LOUCO. Lá não me agrada muito este sistema de ficar privado de um ardente desejo amoroso e de um fervoroso anseio.

SÁBIO. Se tu considerasses quantos males se cancelam, não dirias assim. O vitupério não existiria, a honra não seria atacada, os parentes 
não seriam vituperados, não seriam assassinadas as esposas, nem mortos os maridos, não aconteceriam todos os dias brigas, as mulheres não seriam motivo de infinitos males, desapareceriam os tumultos das bodas, as ocultas traições dos casados, os cafetões, os litígios das recusas, o assassinato por causa dos dotes e as armadilhas dos enganos dos celerados. Até as mulheres por causa de estupro mataram seus maridos, dos quais existem ainda antigos e modernos exemplos. E por uma mulher, por um outro amor, já foram aniquiladas famílias honradas e casas nobilíssimas.

LOUCO. Esta tua razão tem bem um certo quê de verossímil. Mas e se alguém não quisesse trabalhar, o que aconteceria com ele?

SÁBIO. Quem fosse poltrão, e de quem se houvessem suportado uma, duas e três, se ordenava que não comesse, a não ser depois de feito o seu trabalho.

LOUCO. Quem não trabalha não come, portanto?

SÁBIO. Domine ita. E cada um tinha para comer o mesmo tanto que o outro, como já disse.

LOUCO. Um guloso estaria em maus lençóis.

SÁBIO. Que gula queres tu que lhes venha ao apetite, depois de se terem empanturrado com seis ou dez tipos de viandas?

LOUCO. É bem feito. Bem. E agrada-me esta ordenação de haver apagado aquele vitupério da embriaguês, dos vômitos, aquilo de ficar cafajestando cinco ou seis horas à mesa. Realmente assim é melhor. Sei que as compotas, os doces, os cozidos, os molhos, não dariam grandes problemas à voracidade da nossa garganta insaciável! E a carestia não devia ser um grande problema para eles. Mas e se outra terra tivesse vontade de capturar esta aí?

SÁBIO. Para fazer o quê? Primeiro, não existiam armas de ataque ou de defesa; e depois, quem a tivesse tomado, o que teria que fazer? Se desejasse que alguns trabalhassem e outros aproveitassem, poucos tivessem bastante e os outros quase nada; não sei que importância teria isto; porque não existiam as pompas, nem as modas, nem os torneios, nem os prodígios dos cavaleiros errantes, e não compartilhar com este ou aquele. 
E depois quem se incomodaria em fazer isso? com que vontade? com que finalidade?

LOUCO. Semelhante salão me dá a impressão de uma vida de besta em certas coisas, e em certas outras de uma existência de meio homem e meio cavalo, e outra de homem por inteiro. Mas e se alguém ficasse doido, isto é, ficasse furioso e começasse a quebrar, rasgar, destroçar e jogar fora todas as coisas?

SÁBIO. Não é necessário que tu vás tão a fundo; porque as razões para se tornar louco são infinitas, e nós as temos todas; onde, se não houvesse as ocasiões, existiriam poucos loucos ou nós seríamos todos loucos, ao nosso modo.

LOUCO. E com relação a certas coisas, como o vestir, o jogo, o engano, a dor da perda de uma coisa e outras infinitas artimanhas?

SÁBIO. As mesmas coisas.

LOUCO. E quanto a andar a cavalo?

SÁBIO. E onde? para quê? para transportar que coisa? para fazer o quê? para quebrar o pescoço? Os cavalos transportavam a carga; as mulas e os asnos e aqueles que transportavam a esta vila as coisas necessárias a eles, transportavam à cidade dos outros para sustento daquela.

LOUCO. Quem cuidava disso?

SÁBIO. Um homem que morava à porta da cidade, com dez homens que só cuidavam de tomar providências pela sua rua.

LOUCO. E se a alguém desse a vontade de pôr fogo numa casa ou numa vila, para ver uma bela fogueira? ou de dar uma volta com um cavalo carregado por um penhasco abaixo para vê-lo despencar, que aconteceria?

SÁBIO. Aqueles dez homens o levariam até o principal da terra, que lhe daria uma mãozada de arsênico, e o curava de seu humor.

LOUCO. E se esse fosse muito forte?

SÁBIO. Bobagem! Não se pode resistir a tantos, nem se defender de centenas de populares. 
LouCO. Alguém que gostasse de música, que fazia? Existiam músicos?

SÁBIO. No dia em que repousavam, se faziam no templo cem variedades de música; e por serem experimentais e ensaiadas, não se poderia ouvir mais admirável coisa, porque não cuidavam de outra coisa, e toda noite se faziam ouvir no templo; de tal forma que todo mundo se aproveitava desse esforço, dessa virtude, dessa arte, entre um e outro, e (como se diz) uma mão lava a outra.

LOUCO. E existiam pintores e escritores?

SÁBIO. Sim senhor.

LOUCO. Oh! Quando tivessem pintado toda a terra, que exercício era o deles?

SÁBIO. O tempo desgasta; e conforme apareciam coisas de mais valor, apagavam as mais feias, e faziam as coisas mais belas, estórias e fantasias.

LOUCO. Este mundo de loucos, ou de sábios se preferes, que tu viste, era preciso fazê-lo quando não se sabia nada; que aqueles homens eram grandes, como macarrões, e não foram as deusas, os deuses, as ninfas, os pastores, as fadas, as festas, as fábulas, e os poetas em má hora acharam mais idéias, mais numes, mais gênios, sombras, mentiras, que não são as lorotas dos astrólogos. Existiam poetas?

SÁBIO. Sim, mas precisavam suar a camisa, fazendo outras coisas além de versos: ainda, como direi, pescar, caçar, pegar pássaro, fazer redes, e outros ofícios além de cantar versos, que não lhes desse excessiva manufatura de suor.

LOUCO. Puxar uma carreta seria o melhor para eles! Porque ter uma arte assim desesperada nas mãos, lhes sucederia fazer versos bestiais.

SÁBIO. E apesar disso soltam-nos neste mundo, sem dar a eles outro tormento!

LOUCO. Quando um morria? 
SÁBIO. Era levado ao hospital. E faziam como se faz agora nos hospitais entre nós: se enfiava lá, sem grandes velórios, sem sacudi-lo numa volta com a procissão, a exibi-lo vestido de ouro ou de seda; mas como um pedaço de carniça (não mais homem, cadáver e não coisa de qualquer coisa) se enfiava lá na terra, para devolver à terra aquilo que ele havia consumido da terra tanto tempo. E como coisa ordinária se estimava, como acidente natural.

LOUCO. Veja, que quando alguém morria não ficavam tantos testamentos, que causam brigas durante toda a vida de um homem! Veja, que não tinha medo um pai que o filhinho quebrasse os canecos, nem que morresse de fome. Simplesmente acabaram-se tantos depósitos, cofres, ossos, breves, bandeiras, armas, livros, tochas apagadas, estandartes, novelas, fumaças e coisa nenhuma. Veja que eles não tinham de se preocupar se a esposa fosse mulher e senhora [donna e madonna], ou que não tornasse a se casar. Que importa a alguém que torne a se casar ou não? Como se ele fosse voltar para ela. Ora que besteira! Agrada-me esta coisa, oh, como me agrada!

SÁBIO. A todos os loucos agradam as coisas de doidos.

LOUCO. Por minha fé, que ainda tenha gente que dê tantas voltas na cabeça e faça tantas artimanhas, tendo que andar no mundo no escuro; é uma coisa de doidos. Deixar que as coisas tomem seu rumo, em benefício da natureza, se há algo na vida para ser gozado, um homem deve tê-lo. Todos são criaturas de Deus! O que é ruim é distribuído entre muitos, e aquilo que era de um só, é posto em comum. O tal possuía um baú de ducados e os gastou em um ano; se os houvesse gasto apenas em um mês que importaria? Ele os gastaria de qualquer modo. Mas neste país não aconteciam as falências dos comerciantes, que é um estrangulamento, um torniquete, uma maldade: e acontece muitas vezes em nossos dias.

SÁBIO. Isto leva à falência.

LOUCO. Dar um basta à falsificação das coisas e das moedas, ao engano, dando uma coisa por outra, com juras e perjuras; e sobretudo os 
sobressaltos da morte ficavam esquecidos e se poderia viver sem cuidados. As coisas daqueles que morriam, quem herdava?

SÁBIO. Que coisas? Não se possuía nada além daquilo que se tinha em cima do corpo, e em casa a cama onde se dormia. Talvez houvesse a tapeçaria, a prataria, a vaidade, o supérfluo; e aquele que morria por que haveria de se incomodar com aquilo que deixava?

Louco. Também esta é uma bela coisa e o homem se acha fora de um grande trabalho. Mas diga-me, como fizeste tu para sonhar tantas coisas?

SÁBIO. E me parecias ser um daqueles e lá estiveste um tempo, me parece.

LOUCO. Quem eras tu? O que fazias?

SÁBIO. Fui um daqueles do templo.

LOUCO. Devias ter poucas obrigações.

SÁBIO. Toda manhã me cabia ministrar para os da minha avenida e ensinar.

LOUCO. O que te cabia ensinar? $\mathrm{O}$ uso era bom mestre.

SÁBIO. Ensinava a conhecer Deus e a agradecer-lhe por tantos dons e que amassem uns aos outros.

LOUCO. Faz ponto, faz pausa, que isto foi o melhor que tu disseste: conhecer Deus, agradecer-lhe e amar o próximo. E por ora deste teu sonho não quero mais nada. Eu compreendi de que forma era a cidade, e a principal parte do regimento de si mesma. De uma outra vez dirás todo o restante.

SÁBIO. Sim, para mim está ótimo. Eu também estou arrebentado. Adeus.

LouCO. Não leva a mal que eu zombe de tua narrativa, como se diz entre os da terra, porque os loucos não gostam de fazer senão aquilo que lhes dita a cabeça, e a sua bizzarria. 


\section{Notas}

1 Este artigo é parte da produção do Projeto Renascimento e Utopia, coordenado pelo Prof. C.E.O. Berriel. Dele também faz parte a organização de uma antologia de utopias do Renascimento italiano.

2 Substância mineral, corrosivo potentíssimo para uso externo. Pode ser entendido como veneno em sentido geral. 